\section{Evaluation of Sleep Quality in Medical Faculty Residents}

Gamze Küçükosman (1) Özcan Pişkin ๑

Volkan Hancı (D)

Rahşan Dilek Okyay (D Bülent Serhan Yurtlu (1) Serhat Bilir (1) Üstün Sezer (D) Işıl Özkoçak-Turan (1)

\section{ABSTRACT}

Objective: We aimed to determine sleep quality of medical faculty assistants and evaluate this with socio-demographic characteristics.

Method: This cross-sectional study was conducted from June to October 2012, after receiving approval from local Ethics Committee. The data for the research were collected using the Pittsburgh Sleep Quality Index (PSQI) and a socio-demographic questionnaire completed with face-to-face interviews after providing necessary explanation and receiving oral consent of the participants.

Results: A total of 133 residents were included in the study. Significant differences were found between their bedtimes, time to falling asleep, duration of sleep and waking time with mean PSQI scores for residents included in the study according to their clinical departments $(p<0.05)$. According to departments, the highest PSQI scores and worst sleep quality were observed among residents working in surgical

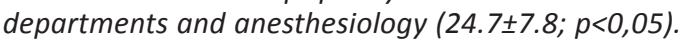

Conclusion: As highest PSQI scores and worst sleep quality were obtained by anesthesiology residents, we have concluded that precautions must be taken for the safety of patients and health workers in surgical departments and intensive care units.

Keywords: medical faculty residents, sleep quality, Pittsburgh Sleep Quality Index

ÖZ

Amaç: Tıp fakültesi asistanlarının uyku kalitesini belirlemeyi ve bunu sosyodemografik özellikleriyle değerlendirmeyi amaçladık.

Yöntem: Bu kesitsel çalışma Lokal Etik Kurulu onayı alındıktan sonra Haziran-Ekim 2012 tarihlerinde gerçekleştirildi. Araştırmanın verileri, katılımcılara gerekli açıklamalar yapılıp sözel izinleri alındıktan sonra, Pittsburg Uyku Kalitesi Indeksi (PUKi) ve sosyodemografik özellikleri sorgulama formu kullanılarak yüz yüze görüşme tekniği ile toplandı.

Bulgular: Çalışmaya 133 asistan dâhil edildi. Çalışmamıza dâhil edilen asistanların çalıştıkları anabilim dallarına göre uykuya yatış saatleri, uykuya dalma, uyku ve uyanma süreleri ile PUKi puan ortalamaları arasındaki fark anlamlı bulundu $(p<0,05)$. Çalıştıkları anabilim dallarına göre asistanların PUKi puanları değerlendirildiğinde en yüksek PUKi puanının ve en kötü uyku kalitesinin cerrahi bilimlerde ve Anesteziyoloji ve Reanimasyon Anabilim Dalı asistanlarında olduğu gözlendi $(24,7 \pm 7.8 ; p<0,05)$.

Sonuç: En yüksek PUKi puanı ve en kötü uyku kalitesinin Anesteziyoloji ve Reanimasyon asistanlarında olması nedeniyle ameliyat odaları ve yoğun bakımlardaki hasta ve sağlık çalışanı güvenliğinin sağlanması için önlem alınması gerektiği kanısına varılmıştır.

Anahtar kelimeler: tıp fakültesi asistanları, uyku kalitesi, Pittsburgh Uyku Kalitesi indeksi
Alındığı tarih: 10.12 .2018

Kabul tarihi: 18.03.2019

Yayın tarihi: 30.09 .2019

Gamze Küçükosman Bülent Ecevit Üniversitesi Tıp Fak. Anesteziyoloji ve Reanimasyon $A D$ 67100 Zonguldak - Türkiye gamzebeu@gmail.com ORCID: 0000-0001-5224-0258

ö. Pişkin 0000-0003-3538-0317 Bülent Ecevit Üniversitesi Tıp Fak. Anesteziyoloji ve Reanimasyon Anabilim Zonguldak - Türkiye

V. Hanci 0000-0002-2227-194X

Dokuz Eylül Üniversitesi Tıp Fak. Anesteziyoloji ve Reanimasyon Anabilim Izmir - Türkiye

R. D. Okyay 0000-0002-0520-7532

Bülent Ecevit Üniversitesi Tıp Fak. Anesteziyoloji ve Reanimasyon Anabilim Zonguldak - Türkiye

B. S. Yurtlu 0000-0003-3020-1586 Dokuz Eylül Üniversitesi Tıp Fak. Anesteziyoloji ve Reanimasyon Anabilim izmir - Türkiye

S. Bilir 0000-0002-4987-1996

Ü. Sezer 0000-0001-7767-5872 Bülent Ecevit Üniversitesi Tıp Fak. Anesteziyoloji ve Reanimasyon Anabilim Zonguldak - Türkiye

I. Ö. Turan 0000-0002-0405-0107 Ankara Eğitim ve Araştırma Hastanesi Anesteziyoloji ve Reanimasyon Anabilim Ankara-Türkiye 


\section{INTRODUCTION}

Quality sleep is a prerequisite for healthy functioning of a person's mind and body ${ }^{[1]}$. Occupation affects the prevalence of sleep disorders and it is known that health workers commonly have sleep problems ${ }^{[2]}$. Long working hours, negative physical and social working conditions, shiftwork, lack of sleep, drowsiness on duty, physical tiredness and high levels of responsibility are among occupational difficulties felt by doctors during their working life ${ }^{[3,4]}$. Tired doctors do not just negatively affect their own personal life, but also the lives of their patients ${ }^{[5]}$.

It is thought that sleep quality of the doctors continuously working in ways that do not coincide with biological rhythms is negatively affected. In the literature there are studies on sleep quality of health workers, but we did not encounter any study researching the sleep quality of medical faculty residents in Turkey. This study aimed to identify the sleep quality of residents of basic, internal and surgical sciences and evaluate it together with their sociodemographic characteristics.

\section{MATERIAL and METHODS}

This cross-sectional study was completed after receiving local ethics committee approval (protocol no: $2012-72-02 / 05$, date: $05 / 29 / 2012$ ) from June to October 2012. Residents aged 24-45 years and receiving training in various medical specialties in our university in basic (Group B), internal (Group I) and surgical (Group S) sciences were included in the study. Our study was planned as a descriptive, crosssectional research, so the sample was not selected and all residents were included in the scope of the research. The research was completed with 133 residents, excluding those who were not on duty during the time the survey was administered and those who did not wish to participate.

To ensure standardization of the survey questions, interviews were conducted with the same research- er who was incognizant of participant names. Research data were collected using a socio-demographic characteristics questionnaire (age, sex, marital status, education duration) and the "Pittsburgh Sleep Quality Index (PSQI)" to measure sleep quality (6). The validity and reliability studies of the Turkish version of the scale were completed by Agargün (7). Data were collected in face-to-face interviews after explaining the study and receiving oral consent.

Statistical Analysis: For statistical analysis the Statistical Package for Social Sciences (SPSS) 15.0 for Windows (SPSS Inc., Chicago, IL, USA) program was used. Data indicating frequency are shown as frequencies ( $n$ ) and percentages (\%). Data with continuous values are shown as mean and standard deviation (mean $\pm S D$ ). For comparison of frequency data, chi-square test was used. For comparison of continuous data, after assessment of normality of data distribution, the Mann Whitney $U$ test was used. A $p$ value of $<0.05$ was accepted as statistically significant.

\section{RESULTS}

The study population consisted of a total of 133 participants including 67 residents in surgical medical sciences, 45 in internal medical sciences and 21 in basic medical sciences. The mean age of residents was $30,23 \pm 3,13$ years, with a mean duration of training of $26,24 \pm 13,63$ months. There was no significant difference identified between the groups in terms of age, sex, marital status and duration of training duration $(p>0.05)$. There was no significant difference observed between the mean total PSQI scores and sex and marital status of participants in the study. There was no correlation between age and PSQI scores, however there was a negative significant correlation between duration of training and PSQI scores ( $p=0,008$, correlation coefficient $=0,229)$. Significant differences were observed regarding bedtime and rising time, time to falling asleep and total duration of sleep and mean PSQI scores bamong participants from different departments in the research $(p<0,005)$ (Table 1$)$. As there were differ- 
Table 1. Bedtime and rising, duration to fall asleep and total sleep duration with comparison of mean PSQI points for assistants mean \pm SD).

\begin{tabular}{|c|c|c|c|}
\hline & $\begin{array}{c}\text { Group S } \\
(n=67)\end{array}$ & $\begin{array}{l}\text { Group I } \\
(n=45)\end{array}$ & $\begin{array}{c}\text { Group B } \\
(n=21)\end{array}$ \\
\hline Bedtime (hr:min) & $00: 30 \pm 01: 35^{*}$ & $00: 00 \pm 01: 37 \dagger$ & $22: 30 \pm 01: 18 \ddagger$ \\
\hline Rising time (hr:min) & $6: 00 \pm 00: 37 *$ & $7: 00 \pm 00: 53+$ & 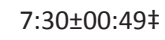 \\
\hline Duration to fall asleep (min) & $17,14 \pm 15,87^{*}$ & $10,97 \pm 9,42+$ & $9,76 \pm 5,58 \ddagger$ \\
\hline Sleep Duration (hours) & $5,52 \pm 0,82 *$ & $7,08 \pm 1,08+$ & $9,09 \pm 0,76 \neq$ \\
\hline PSQI points & $16,71 \pm 8,84^{*}$ & $9,37 \pm 5,08+$ & $4,90 \pm 3,49 \ddagger$ \\
\hline
\end{tabular}

Group S: Surgical medical science, Group I: Internal Medical Science, Group B: Basic Medical Science *p<0.05: Comparing Group $S$ with Group I, Mann Whitney U test $+p<0.05$ : Comparing Group I with Group B, Mann Whitney U test $\neq p<0.05$ : Comparing Group S with Group B, Mann Whitney U test

Table 2. PSQI points based on department (mean \pm SD).

\begin{tabular}{|c|c|c|c|}
\hline Department & PSQI points & Duration to fall asleep (min) & Sleep Duration (h) \\
\hline Anesthesia ( $n=19)$ & $24,73 \pm 7,88$ & $24,68 \pm 22,61$ & $5,26 \pm 0,99$ \\
\hline Brain surgery $(n=3)$ & $17,33 \pm 10,59$ & $33,33 \pm 15,27$ & $6,00 \pm 0,00$ \\
\hline Gynecology $(n=6)$ & $15,83 \pm 9,13$ & $14,33 \pm 9,93$ & $5,50 \pm 0,83$ \\
\hline General Surgery $(n=13)$ & $15,46 \pm 8,50$ & $8,92 \pm 7,52$ & $5,23 \pm 0,59$ \\
\hline Plastic Surgery $(n=6)$ & $15,00 \pm 6,44$ & $9,33 \pm 6,37$ & $5,33 \pm 0,81$ \\
\hline $\operatorname{PTR}(n=3)$ & $11,66 \pm 3,05$ & $13,33 \pm 7,63$ & $7,00 \pm 1,73$ \\
\hline Urology ( $n=9)$ & $11,33 \pm 4,24$ & $17,22 \pm 10,34$ & $6,11 \pm 0,60$ \\
\hline Pedatrics $(n=8)$ & $11,25 \pm 7,08$ & $6,62 \pm 4,68$ & $6,50 \pm 1,06$ \\
\hline Internal Medicine $(n=18)$ & $10,55 \pm 5,50$ & $10,16 \pm 9,16$ & $6,88 \pm 1,18$ \\
\hline ENT $(n=7)$ & $10,28 \pm 3,40$ & $18,28 \pm 11,49$ & $5,85 \pm 0,69$ \\
\hline Orthopedics $(n=3)$ & $9,00 \pm 6,55$ & $11,33 \pm 16,19$ & $5,33 \pm 0,57$ \\
\hline Neurology ( $n=2)$ & $7,00 \pm 2,82$ & $11,50 \pm 12,02$ & $7,50 \pm 0,70$ \\
\hline Cardiology $(n=2)$ & $6,50 \pm 2,12$ & $20,50 \pm 27,57$ & $7,50 \pm 0,70$ \\
\hline Biochemistry $(n=5)$ & $6,40 \pm 3,91$ & $10,00 \pm 5,00$ & $9,00 \pm 0,70$ \\
\hline Psychiatry $(n=5)$ & $6,20 \pm 0,83$ & $8,40 \pm 5,02$ & $8,00 \pm 0,00$ \\
\hline Microbiology $(n=7)$ & $6,00 \pm 4,00$ & $12,14 \pm 8,09$ & $8,85 \pm 0,69$ \\
\hline Dermatology $(n=3)$ & $6,00 \pm 2,00$ & $12,33 \pm 4,61$ & $7,66 \pm 0,57$ \\
\hline Chest Diseases $(n=2)$ । & $5,00 \pm 1,41$ & $7,50 \pm 3,53$ & $8,00 \pm 0,00$ \\
\hline Pharmacology (n=2) & $5,00 \pm 0,00$ & $7,50 \pm 3,53$ & $10,00 \pm 0,00$ \\
\hline Pathology $(n=4)$ & $3,00 \pm 2,70$ & $7,50 \pm 2,88$ & $8,75 \pm 0,95$ \\
\hline Genetics ( $n=2)$ & $3,00 \pm 2,82$ & $7,50 \pm 3,53$ & $10,00 \pm 0,00$ \\
\hline
\end{tabular}

PTR: Physical therapy and rehabilitation, ENT: Ear-nose-throat

ences between the mean total PSQI scores and departments of the participants, the highest PSOI scores and worst sleep quality was observed in residents training in the Anesthesiology and Reanimation Department $(24,7 \pm 7,8 ; p<0,05)$ (Table 2).

\section{DISCUSSION}

This study demonstrated that higher PSQI scores were obtained by the surgical science assistants. Residents of surgical sciences went to bed later, fall asleep at late hours, and wake up were earlier than residents working in the other departments.
Nojomi et al. ${ }^{[8]}$ stated that in a study with 285 medical students and 150 medical residents, only $14 \%$ of them had perfect sleep satisfaction with high prevalence of sleep disorders which was related to age, sex, living conditions and work load. In contrast, when PSQI scores were accepted as a major indicative of low quality sleep as in our study, we didn't notice any impact of age and sex on sleep quality. Ok et al. ${ }^{[9]}$ in a study evaluating sleep quality in doctors working in intensive care units and other departments found no difference in objective sleep parameters defined as sleep efficacy, sleep latency and total duration of sleep, but sleep quality was worse 
for intensive care doctors. In our study, PSQI scores of residents training in surgical sciences were significantly higher with significantly shorter sleeping times.

According to the National Sleep Foundation, the mean sleep duration for an adult is 7-8 hours; however it is reported that sleep duration varies from person to person(10). When healthy adults sleep for less than 5 hours per night on an average, cognitive performance begins to fall. In both short and long term, expression and problem-solving skills apparently deteriorate due to sleep disorder ${ }^{[11]}$. Sarıcaoğlu et al. ${ }^{[12]}$ in a study researching attention and anxiety levels in anesthesia residents working shift work stated that mean sleeping hours were 5-6 hours and there was no difference between the groups.

The performance of anesthesia and surgical residents after working hours and on-call duties is a topic of curiosity researched in a variety of studies and simulations ${ }^{[4,13]}$. In a study evaluating subjective tiredness, sleep duration and sleep quality of anesthesia residents, the participants reported similar levels of drowsiness as narcolepsy patients. This situation did not fully resolve with rest and sleep, while sleep was frequently interrupted and duration of deep sleep was shortened. The majority of anesthesia doctors had severe chronic lack of sleep and disrupted sleep habits due to working long shifts, with reduced attention due to both workload and the effect of sleep requirements, disrupted judgment and delayed decision making ${ }^{[4]}$.

When the correlation between long working hours and preventable medical mistakes was noted, the interest in the effects of sleeplessness on doctors increased ${ }^{[14]}$. Anesthesia residents may remain sleepless for long durations on night duty and have excessive workload. Continuing to work after being on night duty forms a risk in terms of errors when dealing with human health. Sarıcaoğlu et al. ${ }^{[12]}$ evaluated a group of anesthesia residents in terms of errors made during shifts and reported that while the daytime group made no mistakes, the nightshift group made mistakes. This study linked the lack of mistakes made by residents to the presence of supervision by a senior expert. Wu et al. ${ }^{[15]}$ in a study of 254 medical residents reported that $41 \%$ of medical mistakes were due to tiredness and made the interesting conclusion that $31 \%$ of errors resulted in patient death. They stated that this situation was dangerous and worrying for both doctor's health and patient care.

Due to the fact that our study was completed in a single center, and with limited sample size, care must be taken before generalizing these results.

\section{LIMITATIONS}

Present study has several limitations. First data collection of this study was completed at 2012, and data presented in this paper may not reflect the current situation of the residents' sleep patterns at 2017 although such a change is not expected since nothing has changed in their working conditions so far. Second, sample size estimation for this study has not been conducted since the study was planned as a cross-sectional cohort survey reflecting the present situation at that time. However, absence of such a sample size estimation might have brought out unique distribution of specialities of the residents.

\section{CONCLUSION}

We have showed that among residents the highest PSQI scores and worst sleep quality were detected among residents of the anesthesiology and reanimation department. Sleep quality of surgical science residents should be ,mproved to ensure the safety of patients.

Ethics Committee Approval: Bülent Ecevit University Clinical Research Ethics Committee received approval (29.05.2012 / 2012-72-02 / 05).

Conflict of Interest: No conflict of interest was declared by the authors. 
Funding: The authors declared that this study has received no financial support.

\section{REFERENCES}

1. Colten HR, Altevogt BM, editors. Washington (DC): The National Academies Press; 2006. Sleep Disorders and Sleep Deprivation: An Unmet Public Health Problem.

2. ErtelKA, Berkman LF, Buxton OM. Socioeconomicatatus, occupational characteristics, and sleep duration in African/Caribbean immigrants and US white healthcare workers. Sleep 2011;34(4):509-18.

https://doi.org/10.1093/sleep/34.4.509

3. Howard SK, Gaba DM, Rosekind MR, Zarcone VP. The risks and implications of excessive day time sleepness in resident physicians. Acad Med 2002;77(10):101925.

https://doi.org/10.1097/00001888-200210000-00015

4. Howard SK, Gaba DM, Smith BE, Weinger MB, Herndon C, Keshavacharya S, et al. Simulation Study of Rested Versus Sleep-deprived Anesthesiologists. Anesthesiology 2003;98(6):1345-55.

https://doi.org/10.1097/00000542-200306000-00008

5. Papp KK, Stoller EP, Sage P, Aikens JE, Owens J, Avidan $A$, et al. The effects of sleep loss and fatigue on resident-physicians: A multi-institutional, mixed-method study. Acad Med. 2004;79(5):394-406. https://doi.org/10.1097/00001888-200405000-00007

6. Buysse DJ, Reynolds CF, Monk TH, Berman SR, Kupfer DJ. The Pittsburgh Sleep Quality Index: a new instrument for psychiatric practice and research. Psychiatry Res 1989;28(2):193-213.

https://doi.org/10.1016/0165-1781(89)90047-4

7. Agargün MY, Kara H, Anlar Ö. Pittsburgh uyku kalitesi indeksi'nin geçerliliği ve güvenirliliği. Türk Psikiyatri
Dergisi 1996;7(2):107-15.

8. Nojomi M, Bandi MFG, Kaffashi S. Sleep pattern in medical students and residents. Arch Iran Med. 2009;12(6):542-9.

9. Ok G, Yılmaz H, Tok $G$, Erbüyün $K$, Çoban $S$, Dinç $G$. Evaluating sleep characteristics in intensive care unit and non-intensive care unit physicians. Anaesth Intensive Care 2011;39(6):1071-5. https://doi.org/10.1177/0310057X1103900614

10. Zee PC. The Normal Duration of Daily Sleep for Different Age Groups. Medscape Family Medicine. 2005;7(2) (Online) 2005. (Cited 25th February 2013) Availablefrom URL: http://www.medscape.org/ viewarticle/511229

11. Veasey S, Rosen R, Barzansky B, Rosen I, Owens J. Sleep loss and fatigue in residency training. JAMA 2002;288(9):1116-24. https://doi.org/10.1001/jama.288.9.1116

12. Sarıcaoğlu F, Akıncı SB, Gözaçan A, Güner B, Rezaki M, Aypar Ü. Gece ve gündüz vardiya çalışmasının bir grup anestezi asistanının dikkat ve anksiyete düzeyleri üzerine etkisi. Türk Psikiyatri Dergisi 2005;16(2): 106-12.

13. Murray D, Dodds C. The effect of sleep disruption on performance of anaesthetists - A pilot study. Anaesthesia 2003;58(6):520-5. https://doi.org/10.1046/j.1365-2044.2003.03131.x

14. Landrigan $C P$, Rothschild JM, Cronin JW, Kaushal R, Burdick E, Katz JT, et al. Effect of reducing interns' workhours on serious medical errors in intensive care units. N Engl J Med. 2004;351(18):1838-48. https://doi.org/10.1056/NEJMoa041406

15. Wu AW, Folkman S, McPhee SJ, Lo B. Do house officers learn from their mistakes? JAMA 1991;265(16):208994. https://doi.org/10.1001/jama.1991.03460160067031 